\title{
Responding to Refugees in Australia: What is the Christian Response?
}

\section{Tim Costelloa \& Nils von Kalm ${ }^{b}$}

\author{
${ }^{a} \operatorname{Dr}($ Sac Theo), Chief Advocate, World Vision, Australia \\ ${ }^{\mathrm{b}}$ Grad Dep Theol, BLitt Soc, Church and Community Engagement, Anglican Overseas Aid
}

\begin{abstract}
What role should Christians play in dealing with the march of displaced people across the globe? What moral and spiritual obligations do we owe the distant stranger - the refugee? We can learn from the experience of the Hebrew refugees leaving Egypt and the inclusive nature of the early Christian Church. In the Australian context, this article explores the historical and current attitudes towards asylum seekers and calls for a faith-led movement to stand shoulder to shoulder with those who are demonised and dehumanised.
\end{abstract}

\section{Current State of the World's Refugees}

According to the UN Refugee Agency, there are currently 68.5 million people around the world who have been forcibly displaced. More than 25 million of these people have fled to other countries as refugees. From Gaza to northern Uganda, to the Rohingya people, to Yemen, refugees are struggling just to survive.

The majority of the world's refugees are also hosted by low- and middle-income countries. These people are often helped by NGOs like World Vision through the provision of aid, including food, special nutrition treatment for malnourished children and breastfeeding mothers, livelihood training, seeds and farming supplies, household items like bed nets and blankets, and water and sanitation services.

The 1951 UN Convention on Refugees defines a refugee as any person who,

... owing to well-founded fear of being persecuted for reasons of race, religion, nationality, membership of a particular social group or political opinion, is outside the country of his nationality and is unable or, owing to such fear, is unwilling to avail himself of the protection of that country; or who, not having a nationality and being outside the country of his former habitual residence as a result of such events, is unable or, owing to such fear, is unwilling to return to it. ${ }^{1}$

The Convention also outlines the rights of the displaced, as well as the legal obligations of states to protect them. An asylum seeker is an individual seeking international protection. Not every asylum seeker will ultimately be recognised as a refugee, but every refugee is initially an asylum seeker.

What is the role of the Christian toward the stranger in this current global crisis of displacement?

\section{The Moral Question for Christians}

The plight of refugees raises a moral question for Christians. It is one of the great moral questions 
of our time. It is the question of my duty towards the refugee.

In Christian thought, we start from the biblical teaching in the first chapter of Genesis that everyone, rich and poor, national or refugee alike, is made in the image of God. All deserve respect and protection. This is seen in the experience of the people of Israel leaving Egypt as strangers, becoming refugees and being forced to travel through a harsh wilderness. The Bible describes the lessons gained from their suffering in the desert. God commanded Israel: "Do not oppress a foreigner; you yourselves know how it feels to be foreigners, because you were foreigners in Egypt" (Ex 23:9).

Later, God told Israel: "When a foreigner resides among you in your land, do not mistreat them. The foreigner residing among you must be treated as your native-born. Love them as yourself, for you were foreigners in Egypt" (Lev 19:33-34).

The book of Ruth tells the story of a foreigner who came to Israel, and worked as a labourer in the fields, hoping for a better life. It is this refugee who is the ancestor of King David and Joseph, the earthly father of Jesus.

The obligation to the distant stranger was even stronger in the gospels. It started with the identification of Jesus himself as a refugee, when his parents were forced to flee with the young Jesus to Egypt to escape the murderous intent of Herod (Mt 2:13-23). In Jesus' own ministry, our duty to care for the refugee is seen in the overarching question in Jesus' teaching: "Who is my neighbour?" (Lk 10:29). The famous Parable of the Good Samaritan directs the Christian to care for the stranger regardless of their background. Similarly, in the parable of the sheep and the goats in Matthew 25:31-46, Jesus spoke of how the righteous should welcome the stranger. "I was hungry and you gave me food, I was thirsty and you gave me drink, I was a stranger and you welcomed me." Jesus' intimate identification with the refugee is seen in his follow-up statement that when we do it to them, we are doing it to Jesus himself.
We have been created by God to love our neighbour; it is part of the greatest commandment that Jesus gave (Mt 22:39). In reference to refugees, this means not turning away from the needs of the world's refugees. We are commanded to be intentional about love. When we turn away from refugees, we turn away from God. Christianity is about learning to love like Jesus loved. And Jesus loved the poor and Jesus loved the broken. He called us to practice that radical love.

We also read in Acts 2 and 4 that the members of the early church sold their property and possessions and shared the money with those in need. Christians extended love way beyond the boundaries of family and congregation to their pagan neighbours. This was counter-intuitive because at the time justice demanded that everyone got what they deserved. Mercy, grace, and love shown by the Christians were uncharacteristic in the ancient world. It was distinct in a "user pays" society.

The apostles turned the world upside down with "good news of great joy for all the people" (Luke 2:10). They healed the sick, cast out devils, and performed signs and wonders on a consistent basis. Genuine Christianity is daring to step outside the status quo to follow the beat of a different drummer. It calls followers of Jesus to fight for the rights of invisible people everywhere. They are neither rich nor powerful.

Jesus turned away from respectable society and made the marginalised his friends. $\mathrm{He}$ addressed crowds of people, many of whom were desperately poor, often without work or money. Jesus was saying, to everyone who would listen, that relationships with the marginalised provided the key to life. He said that the remedy to the invisibility of "the other" was simple acceptance. We had to stand shoulder to shoulder with those in society who were demonised and dehumanised.

The early Christian movement continued the example of Jesus in this care for their neighbours. The sociologist, Rodney Stark, points out that the early church grew very rapidly during the first centuries after the Resurrection because the love 
shown by Christians to all was genuinely persuasive. ${ }^{2}$ During famine and plague, Christians, at immense cost and risk, cared for the weak and sick who had been abandoned, not just their fellow Christians. $^{3}$ A hallmark of true Christian faith is that it welcomes refugees with open hearts and arms, and advocates on their behalf. They are our brothers and sisters in the family of humanity.

However, we live in an age of social and economic insecurity and a sense of cultural and spiritual drift colours our attitudes towards issues of cultural identity and social cohesion. In Europe fear of terror is real, and consequently, so is a fear of outsiders and newcomers. It can be argued that this fear is reflected in the Brexit vote and the ascendancy of right-wing populist parties with an anti-immigration platform. In our country, Australia, fear of "the other" has led to a toxic debate on refugees and asylum seekers that has damaged our collective soul.

\section{The Complex Australian Experience}

Australia has a complex and ambivalent attitude to migration in general and refugees in particular. Many thousands of Australians share a sense of shame about Australia's current border policing policies. The White Australia policy of yesteryear is now a ghost that haunts current policies. The echo of that policy is reflected in contemporary Parliamentary debate. ${ }^{4}$ The populist ideology is that national rights have greater importance than human rights. Australia's current refugee policy - which places those trying to escape persecution by boat into inhuman offshore detention camps - is designed to appeal to our insecurities by linking immigrants, terrorism, and competition for jobs. It panders to our common fear of the foreign, of the "other."

Contemporary Australia is a product of its own history. Being an island nation, a "western nation" dislocated from Europe, has coloured our thinking in the past 200 years or so. The attitude prevails that we can quarantine ourselves from disruptive global forces. This idea of isolating ourselves ranges from dealing with refugees, asylum seekers and migrants, to terrorism and the uncomfortable ideas and ideologies that feed it, to the cost and inconvenience of shifting to a low carbon economy if we are to avoid catastrophic climate change.

This thinking comes in several manifestations, from mild to manic - at times including, among others, economic protectionism, the White Australia Policy, a rigorous system of quarantine, obsessive border protection, cultural xenophobia, and a radical scepticism about international institutions.

The very first Act passed in the new Parliament of Australia in 1901 - the Immigration Restriction Act - gave effect to a White Australia Policy. ${ }^{5}$ The Act excluded non-white potential immigrants (and anyone else thought undesirable) primarily by introducing a dictation test where potential immigrants were required to undergo dictation in any European language. It gave official blessing to Australia's isolationist stance. The philosophy was that we were safer if we were a fortress cut off from the rest of the world.

The concept of "Fortress Australia" still has its supporters. It ignores the reality that Australians - via trade, migration, exchange of technology, tourism, and our personal friendships with those in other nations and support of international charities - constantly engage with the world. Australia has always been dependent on external exchanges. Aside from our indigenous people, we are all immigrants or descendants of immigrants- a nation largely comprised of "boat people." Much of Australia's greatness comes from that fact. About a quarter of Australians were born overseas, and almost half the population has at least one parent who was born overseas. ${ }^{6}$ More than a third of chief executives of ASX100 companies are foreignborn. $^{7}$

In 1959, while marking World Refugee Year, then Prime Minister Robert Menzies said:

It is a good thing that Australia should have earned a reputation for a sensitive understanding of the problems of people in other lands; that we should not come to be regarded as people who are 
detached from the miseries of the world. I know that we will not come to be so regarded, for I believe that there are no people anywhere with warmer hearts and more generous impulses. ${ }^{8}$

In the current century, our attitude towards refugees has changed. It is now more in line with former Prime Minister John Howard's 2001 statement: "We will decide who comes to this country and the circumstances under which they come."

The stopping of asylum seeker boats and the detention of their occupants in off-shore detention centres has become bipartisan policy among Australia's two main political groupings - the Labor and the Liberal-National Coalition. This policy has been condemned by the Australian Human Rights Commission, ${ }^{10}$ Amnesty International, ${ }^{11}$ and the United Nations Human Rights Council. ${ }^{12}$

\section{Characterisation of "Good" and "Bad" Refugees}

A succession of Australian political leaders, anxious to sway public opinion on refugees, have divided asylum seekers into two disparate groups those who are considered "genuine" and those who are considered undeserving and illegal (especially those arriving by boats). The Liberal/National Coalition's Operation Sovereign Borders Policy of 2013 made the clear distinction. It stated,

\begin{abstract}
More than 14,500 desperate people have been denied a place under our offshore humanitarian programme because those places have been taken by people who have arrived illegally by boat. These people are genuine refugees, already processed by United Nations agencies, but they are denied a chance at resettlement by people who have money in their pocket to buy a place via people smugglers. ${ }^{13}$
\end{abstract}

In 2012, then Opposition Leader and soonto-be prime minister Tony Abbott described boat people as "unchristian" by "coming through the back door" and should not be encouraged to "jump the queue"14 with people-smugglers (who are defined by the United Nations as people who gain financially or through some other material benefit from the procurement of the illegal entry of a person into a State Party of which the person is not a national or a permanent resident).

The Australian public though has generally expressed more openness. A 2016 poll showed that a majority of Australians - 63\% - opposed the bipartisan policy that refugees who arrive in Australia by boat should never be allowed to settle in the country, instead saying those found to have a valid claim for protection should be allowed to stay in Australia. ${ }^{15}$ That same year, in the run-up to the 2016 federal election, the then Immigration Minister Peter Dutton linked asylum seekers with terrorism. ${ }^{16}$

In the Australian church the response was mixed. A National Church Life Survey in 2011 polled a sample of Catholic, Anglican, and Protestant church attenders and found that those who believed the refugee intake should be at a lower level made up $32 \%$ of responses. The proportion of attenders who believed the intake should be at the existing level (26\%) was the same as that who thought it should be at a greater level $(26 \%)$. A minority of $16 \%$ were unsure. ${ }^{17}$

The opposition to refugee settlement in Australia has a link to anti-Islamic feeling in some sectors of the community. According to a University of Melbourne study, many people concerned about the "Islamisation" of Australia were "unshakably convinced" that Muslims were universally overpowering Christian traditions such as Christmas cards and the singing of carols in schools, despite having no such direct or secondhand experiences. ${ }^{18}$ A 2015 poll showed Australians, on average, estimate Muslims make up $12 \%$ of the Australian population. ${ }^{19}$ But according to the 2016 Census, the proportion of the population identifying as Muslim was $2.6 \%{ }^{20}$ 
Scott Higgins' book, Boundless Plains to Share? Australia, Jesus and refugees, points out that Australia is a swirling mass of contradiction, fear, and hope when it comes to refugees. ${ }^{21}$ Our status as an island nation far removed from the world's conflict hotspots means that we have very few refugees showing up on our borders seeking protection, yet we have imagined a crisis into being and enacted harsh measures to assert control over our fictional predicament. Higgins says our public discourse is characterised by half-truths, misconceptions. and outright falsehoods. We have learned to fear asylum seekers and refugees. He says the public discourse around refugees would be different if we began by listening to their stories. Stories bring us down out of the clouds of abstraction, ideology, mythology, and politicking to the realities of life. They also humanise people, making it more difficult for us to fear them and easier to love them.

\section{Faith Can Fuel Change}

A collective sense of peace and justice for all has clearly not yet been achieved. Christians, however, should aim to counter the dominant narrative of isolationism and fear and are called to unveil a pragmatic and inspiring view of a better world.

During the past year, one of the authors has travelled to several refugee camps. One horrifying scene was the vast congested refugee camp of Cox's Bazar, Bangladesh overwhelmed by more than 600,000 people who identify as Rohingya Muslims fleeing their burning villages in Myanmar. The following month involved a visit to Manus Island as part of a fact-finding mission under the auspices of the Australian Council for International Development to witness the conditions of refugees and asylum seekers stalled there for more than four years under Australia's border protection policies. In both Cox's Bazar and Manus, the overwhelming impression was of an absence of hope, the most shocking of all deprivations.

A subsequent visit to Uganda then provided a sharp contrast. This relatively poor nation has welcomed hundreds of thousands of South Sudanese fleeing famine and war. The fact that one million South Sudanese have fled for their lives across Uganda's border seeking safety since the start of the war in 2013 shows the extent of Uganda's generosity.

The plight of refugees and asylum seekers strikes at the heart of our faith. For those who claim the label "Christian" the choice is clear. A key nonnegotiable component of Jesus' gospel is to reach out to the excluded, the poor and those in despair, as well as to protest injustice. It should concern every Christian that there are children in detention centres who are living lives behind bars, lives that were already blighted in some way by the circumstances that pushed their families from their homes, lives that are suspended.

Historically, many great social movements have their roots from within faith communities from the slavery abolitionist movement to civil rights, anti-apartheid roles in South Africa, and more recently, climate change debates. Faith has been the fuel that has fed a passionate quest for justice and inspired many movements for social reform.

Fifty-one years ago, Martin Luther King, Jr. sat in a jail cell in Birmingham, Alabama and wrote a letter to clergymen in white mainline churches. In it he expressed his disappointment in the church's inability to be a people formed more by a vision of Jesus than by fear of cultural rejection. Dr King wrote: "If today's church does not recapture the sacrificial spirit of the early church, it will lose its authenticity, forfeit the loyalty of millions, and be dismissed as an irrelevant social club with no meaning."22 Elsewhere he said: "An individual has not begun to live until he can rise above the narrow horizons of his particular individualistic concerns to the broader concerns of all humanity." 23

\section{Recommendations for Action}

There is an urgent need for ordinary Christians to continue to engage on the issue of refugees and inform the debates about offshore detention systems that imprison vulnerable people. Movements like Love Makes a Way are gaining 
momentum amongst many Christians. ${ }^{24}$ This particular movement is well-planned and intelligent in its ideology and methods, particularly in the way it mobilises Christians to sit and pray in the offices of Members of Parliament across Australia.

More generally, we endorse the following recommendations of the Australian Human Rights Commission as an effective and compassionate advocacy in the treatment of refugees and asylum seekers in the Australian context ${ }^{25}$ :

1. The Australian Government should end the system of mandatory and indefinite immigration detention.

2. The need to detain should be assessed on a case-by-case basis taking into consideration individual circumstances.

3. Australian Government policy should be reformed so that individuals in immigration detention who have received an adverse security assessment can be considered for release from detention or for placement in a less restrictive form of detention.

4. The Australian Government should comply with its international human rights obligations by providing for a decision to detain a person or to continue a person's detention to be subject to prompt review by a court.

5. The Australian Government should work towards a uniform model of community assessment and placement for asylum seekers, irrespective of their place or mode of arrival in Australia.

6. The Australian Government should introduce reforms so that refugees who have received adverse security assessments from the Australian Security Intelligence Organisation are provided with appropriate information and access to effective mechanisms to review their assessments.

7. The Australian Government should develop a formal statelessness determination mechanism that recognises both de jure and de facto statelessness and establish administrative pathways for the grant of substantive visas to stateless persons who have been found not to be refugees or otherwise owed protection.

8. A uniform national policy on the use of restrictive places of detention should be developed and cover all places of detention that may be used for observation and segregation.

\section{Conclusions}

With millions of people displaced worldwide, more than half of them children, displacement is the biggest humanitarian challenge of our times. Whilst difficult, we must find ways to give dignity and freedom - not cruelty and despair. Purpose unites us and focuses our dreams for a fairer world. It defines and shapes us. It enables us to do great things.

We have an abiding belief that all of us have to be a part of the solution. We all have gifts, privileges, and talents to make a difference.

\section{References}

1. United Nations High Commission for Refugees. Convention and protocol relating to the status of refugees. December 2010. Available from: http://www.unhcr.org/en-au/3b66c2aa10.

2. Stark R. The Rise of Christianity. San Francisco, CA: Harper; 1997. pp. 74-75.

3. Ferngren GF. A new era in Roman healthcare: How the early church transformed the roman empire's treatment of its sick. Healthcare and hospitals in the mission of the Church. Christian History 101. 2011. pp. 6-12. Available from: https://christianhistoryinstitute.org/magazine/issue/ healthcare-and-hospitals-in-the-mission-of-thechurch

4. Anning F. First speech. Australian Senate. Parliament of Australia. 14 Aug 2018. Available from:

https://www.aph.gov.au/Parliamentary_Business/H ansard/Hansard_Display?bid=chamber/hansards $/ 3 \mathrm{c}$ ee6e8f-15b4-468c-91dd-05ded6631e43/\&sid=0136

5. National Archives of Australia. Immigration Restriction Act 1901 (commonly known as the White Australia Policy). Available from: http://www.naa.gov.au/collection/a-z/immigrationrestriction-act.aspx $\backslash$

6. Australian Bureau of Statistics. Census of population and housing: Australia revealed, 2016. 27 June 2017. Available from: 
http://www.abs.gov.au/ausstats/abs@.nsf/Latestpro ducts/2024.0Main\%20Features22016

7. Durkin P, Bailey M. More than a third of ASX100 CEOs are foreign. Financial Review. 23 April 2017. Available from: http://www.afr.com/leadership/more-than-a-thirdof-asx100-ceos-are-foreign-20170420-gvoiny

8. Menzies R. Broadcast by the prime minister (Mr. Menzies) for the opening of the world refugee year in Australia. 27 Sept 1959. Available from: http://pmtranscripts.pmc.gov.au/release/transcript$\underline{108}$

9. Howard J. Australian Federal Election Speeches. 28 Oct 2001. Available from: https://electionspeeches.moadoph.gov.au/speeches/ 2001-john-howard

10. Australian Human Rights Commission. Pathways to Protection: A human rights-based response to the flight of asylum seekers by sea. Report 2016. Available from: https://www.humanrights.gov.au/sites/default/files/ 20160913_Pathways_to_Protection.pdf

11. McCarthy-Naidoo K. Closing the offshore detention centres. 22 June 2017. Amnesty International. Available from: https://www.amnesty.org.au/close-the-offshoredetention-centres/

12. Doherty B. Scathing UN migration report mars Australia's first week on human rights council. The Guardian. 1 Mar 2018. Available from: https://www.theguardian.com/australianews/2018/mar/02/scathing-un-migration-reportnot-ideal-start-to-australias-human-rights-counciltenure

13. The Coalition's Operation Sovereign Borders Policy. July 2013; pg. 3. Available from: http://past.electionwatch.edu.au/sites/default/files/d ocs/Operation\%20Sovereign\%20Borders_1.pdf

14. Burnside, J. Boat people un-Christian? Wrong, Mr Abbott. ABC. 11 July 2012. Available from: http://www.abc.net.au/news/2012-07-11/burnsidean-unchristian-view-of-asylum-seekers/4123872

15. The Australia Institute. Asylum Seeker Policy Polling Brief. June 2016. Available from: http://www.tai.org.au/sites/defualt/files/Polling\%2 0Brief\%20-\%20May\%202016\%20\%20Asylum\%20Seeker\%20Policy.pdf

16. The Sydney Morning Herald. Federal election 2016: Immigration Minister Peter Dutton links asylum seekers with terrorism. 1 July 2016. Available from: https://www.smh.com.au/politics/federal/federal- election-2016-immigration-minister-peter-duttonlinks-asylum-seekers-with-terrorism-20160701gpvykq.html

17. Powell R, Pepper M, Bevis S. Refugee intake Church attenders' views, NCLS Research Fact Sheet 14017. Adelaide: Mirrabooka Press. 2014. Available from:

http://www.ncls.org.au/download/doc5566/2011\% 20NCLS\%20Research\%20Collection\%20\%20March\%202016.pdf

18. Hasham N. Some voters believe asylum seekers get \$10,000 and Nike shoes. The Age. 10 March 2016. Available from:

https://www.theage.com.au/politics/federal/somevoters-believe-asylum-seekers-get-10000-andnike-shoes-20160310-gnfbdo.html

19. Ipsos Game Changers. Perils of perception perceptions are not reality: What the world gets wrong. 14 Dec 2016. Available from: https://www.ipsos.com/en-au/perils-perceptionperceptions-are-not-reality-what-world-gets-wrong

20. Australia Bureau of Statistics. 2016 Census data reveals "no religion" is rising fast. 27 June 2017. Available from: http://www.abs.gov.au/AUSSTATS/abs@.nsf/med iareleasesbyReleaseDate/7E65A144540551D7CA2 58148000E2B85?OpenDocument

21. Higgins SJ. Boundless plains to share? Australia, Jesus and refugees. A Just Cause. 2014.

22. King ML. Letter from a Birmingham jail. 16 April 1963. African Studies Center, University of Pennsylvania. Available from: http://www.africa.upenn.edu/Articles_Gen/Letter Birmingham.html

23. King ML. Conquering self-centeredness: Sermon delivered at Dexter Avenue Baptist Church. Montgomery, Alabama, USA. 11 Aug 1957. Available from: https://kinginstitute.stanford.edu/kingpapers/documents/conquering-self-centerednesssermon-delivered-dexter-avenue-baptist-church

24. Love Makes a Way. [Internet] Available from: http://lovemakesaway.org.au/

25. Australian Human Rights Commission. Community arrangements for asylum seekers, refugees, and stateless persons Recommendations. Available from: https://www.humanrights.gov.au/publications/com munity-arrangements-asylum-seekers-refugeesand-stateless-persons-recommendations

Peer Reviewed: Submitted 9 June 2018, Accepted 7 Sept 2018, Published 22 Sept 2018.

Competing Interests: None declared.

Sept 2018. Christian Journal for Global Health, 5(2):21-28. 
Correspondence: Rev Tim Costello, World Vision, Australia

Tim.Costello@worldvision.com.au

Cite this article as: Costello T, von Kalm N. Responding to refugees in Australia: what is the Christian response? Christian Journal for Global Health. Sept 2018; 5(2):21-28.

(C) Authors This is an open-access article distributed under the terms of the Creative Commons Attribution License, which permits unrestricted use, distribution, and reproduction in any medium, provided the original author and source are properly cited. To view a copy of the license, visit http://creativecommons.org/licenses/by/4.0/

wWw.cjgh.org

Sept 2018. Christian Journal for Global Health, 5(2):21-28. 